\title{
Expression and significance of hypoxia-inducible factor-1 alpha and MDR1/P-glycoprotein in human colon carcinoma tissue and cells
}

\author{
Zhenyu Ding $\cdot$ Li Yang $\cdot$ Xiaodong Xie $\cdot$ Fangwei Xie $\cdot$ \\ Feng Pan $\cdot$ Jianjun Li $\cdot$ Jianming He $\cdot$ Houjie Liang
}

Received: 31 January 2009 / Accepted: 8 February 2010 / Published online: 9 March 2010

(C) The Author(s) 2010. This article is published with open access at Springerlink.com

\begin{abstract}
Purpose Hypoxia in tumors is generally associated with chemoresistance and radioresistance. However, the correlation between the heterodimeric hypoxia-inducible factor-1 (HIF-1) and the multidrug resistance (MDR1) gene/transporter P-glycoprotein (P-gp) has not been clearly investigated. This study aims at examining the expression levels of HIF- $1 \alpha$ and MDR1/P-gp in human colon carcinoma tissues and cell lines (HCT-116, HT-29, LoVo, and SW480) and ascertaining whether HIF- $1 \alpha$ plays an important role in tumor multidrug resistance with MDR1/P-gp.

Methods The expression and distribution of HIF- $1 \alpha$ and P-gp proteins were detected in human colon carcinoma tissues and cell lines by immunohistochemistry and immunocytochemistry using streptavidin/peroxidase (SP) and double-label immunofluorescence methods. HIF- $1 \alpha$ and MDR1 mRNA expression levels in cell lines were analyzed using RT-PCR under normoxic and hypoxic conditions, respectively.

Results The immunohistochemical method shows that HIF- $1 \alpha$ and P-gp expression were not correlated with gender, age, location, and differentiation degree $(P>0.05)$. However, the expression of HIF- $1 \alpha$ and P-gp at different
\end{abstract}

Grant support: National Nature Science Foundation of China, No.30973430.

Z. Ding · L. Yang · F. Xie · F. Pan · J. Li · J. He · H. Liang $(\bowtie)$

Department of Oncology, Southwest Hospital,

Third Military Medical University, 30 Gaotanyan Street,

Shapingba District, Chongqing 400038, China

e-mail: lianghoujie@sina.com; dingdzy@yahoo.com.cn

Z. Ding $\cdot X$. Xie

Department of Oncology,

General Hospital of Shenyang Military Region,

Shenyang 110840, Liaoning, China
Dukes' stages and whether involved in lymphatic invasion shows a significant difference $(P<0.05)$. Correlation analysis displays that HIF- $1 \alpha$ protein expression was correlated significantly with P-gp expression $(P<0.01)$. Doublelabel immunofluorescence demonstrates that coexpression of HIF- $1 \alpha$ and P-gp does exist in human colon carcinoma tissues. The mRNA expression of HIF- $1 \alpha$ and MDR1 was detected in the four human colon carcinoma cell lines under both normoxia and hypoxia. Optical density values representing mRNA expression levels of HIF- $1 \alpha$ and MDR1 were found to be significantly higher in the same type cells under hypoxic conditions than that under normoxic conditions, respectively $(P<0.01)$. However, no significant differences of HIF- $1 \alpha$ or MDR1 mRNA expression were found among these cell lines, which exposed under the same $\mathrm{PaO}_{2}$ cultural conditions $(P>0.05)$. And the immunocytochemistry results were corresponding with the analysis of mRNA expression.

Conclusions These results suggest that hypoxia induce the expression of HIF- $1 \alpha$ and MDR1/P-gp in colon carcinoma and HIF- $1 \alpha$ expression may be associated with the gene MDR1 (P-gp) and interactively involved in the occurrence of tumor multidrug resistance.

Keywords Hypoxia $\cdot$ Hypoxic-inducible factor- $1 \alpha$. Multidrug resistance $\cdot$ P-glycoprotein $\cdot$ Human colon carcinoma

\section{Introduction}

Deficiencies in oxygenation are widespread in solid tumors. Hypoxic cell areas have been identified in several studies, either by immunostaining of hypoxic cells in sections of rodent and human tumors or by oxygen pressure 
measurements in tumor tissue by the use of needle electrodes (Durand and Raleigh 1998; Partridge et al. 2001). And HIF-1 plays a central role in the tumor bionomics changes caused by hypoxia.

HIF-1 is a bHLH-PAS transcription factor that plays an essential role in oxygen homeostasis, which is a heterodimer composed of HIF- $1 \alpha$ and HIF- $1 b$ subunits. Both transcription factors contain basic helix-loop-helix (bHLH) and per-ARNT-sim (PAS) domains that are required for dimerization and DNA binding, and these domains control various critical embryogenic and pathogenic events (Iyer et al. 1998; Semenza 2000). HIF-1 $\beta$ has been previously identified as an aryl hydrocarbon nuclear translocator (ARNT), whereas HIF- $1 \alpha$ is the unique, $\mathrm{O}_{2}$-regulated subunit that determines HIF-1 activity (Semenza 1999). Under non-hypoxic conditions, HIF- $1 \alpha$ is subject to rapid ubiquitination and proteasome degradation. This degradation is affected by the von Hippel-Lindau (VHL) protein (Maxwell et al. 1999). HIF-1 $\alpha$ has been recognized as an important regulatory protein in the transcription of a large number of genes related to glucose transport, glycolysis, erythropoiesis, cell proliferation/survival, and angiogenesis (Semenza 2002). In human tumors, overexpression of HIF- $1 \alpha$ may activate metabolic and pathogenic pathways that are related to tumor angiogenesis, growth, invasion and metastasis (Fang et al. 2007; Jiang and Feng 2006; Koukourakis et al. 2002; Semenza 1999).

Thomlinson and Gray (Thomlinson and Gray 1955) firstly proposed that within the tissue of solid tumors viable hypoxic conditions exist and hence chemotherapy-resistant and radiotherapy-resistant cells occur at a constant distance $(100.150 \mu \mathrm{m})$ between blood vessels and necrotic tissue in areas of reduced oxygen supply. There is also general consent that hypoxia in the depth of solid tumors dramatically decreases the chemosensitivity of tumor cells and that experimental hypoxia promotes drug resistance to anticancer agents in a variety of cell lines (Teicher 1994). However, no correlation between hypoxia and either increased expression or amplification of genes conferring multidrug resistance (MDR), e.g., the genes for the MDR transporters P-glycoprotein (P-gp), MDR-associated protein, or lung resistance-associated protein, has yet been presented. These genes, which constitute the major constraint to increased efficacy of chemotherapeutic anticancer agents, may be regulated by HIF-1, which are stabilized under hypoxia but undergo enhanced degradation under normoxia (Hofer et al. 2002; Semenza 2001). Therefore, the purpose of this study was to investigate the expression levels and relationship between HIF- $1 \alpha$ and MDR1/P-gp in human colon carcinoma tissues and cell lines and exploring whether HIF- $1 \alpha$ plays an important role in tumor multidrug resistance with MDR1/P-gp.

\section{Materials and methods}

\section{Cell cultures}

The human colon carcinoma cell lines (HCT-116, HT-29, LoVo, SW480) were stored in our laboratory and were cultured in high-glucose Dulbecco's modified Eagle's medium (DMEM; Gibco Corporation, USA), supplemented with $10 \%$ fetal bovine serum (Hyclone, USA) and antibiotics (1\% penicillin and $1 \%$ streptomycin). For hypoxia exposure, four types of cells were cultured for $24 \mathrm{~h}$ in a modulator incubator chamber at $37^{\circ} \mathrm{C}$ with $1 \% \mathrm{O}_{2}, 5 \% \mathrm{CO}_{2}$, and $94 \% \mathrm{~N}_{2}$.

\section{Patients and tumor specimens}

Fifty-eight tissue specimens of colon carcinomas obtained from the Department of Pathology, Southwest Hospital, Third Military Medical University, Chongqing, China, were used in this immunohistochemistry (IHC) study (Table 1). The patients ranged in age from 21 to 85 (mean, 54 years), including 30 men and 28 women. The whole specimens were classified according to level of differentiation: 8 cases were well differentiated, 35 were moderately well differentiated, and 15 were poorly differentiated. The tumors were classified into 4 stages according to the Dukes' system as follows: Dukes A (11), Dukes B (27), Dukes C (15), and Dukes D (5). None of the patients had a known history of familial polyposis syndrome or hereditary nonpolyposis colorectal cancer syndrome. All above resected tissue specimens were fixed in $10 \%$ formalin, embedded in paraffin, and cut into $4-\mu \mathrm{m}$ serial sections. Moreover, eight fresh surgical specimens of colon carcinomas (men 4, women 4 ; patients mean age 56, ranging from 35 to 78 ) were used in the study of double-label immunofluorescence. The level of differentiation was that 2 cases were well differentiated, 3 were moderately well differentiated, and 3 were poorly differentiated. The Dukes' stages were that Dukes A and B (3), Dukes C and D (5). All specimens were resected surgically between 2004 and 2006, and the diagnoses were confirmed pathologically. No patients had undergone preoperative radiotherapy or chemotherapy. The clinical features of all patients, including stage, histological type, liver metastasis, and lymph node metastasis were obtained from clinical and pathological reports.

\section{Experimental groups}

Approximately $10^{6}$ cells were plated on culture dishes $(60 \mathrm{~mm})$. The experimental samples were divided into two groups: (1) normoxia group, cultured under normoxic conditions $\left(20 \% \mathrm{O}_{2}, 5 \% \mathrm{CO}_{2}\right.$, and $\left.75 \% \mathrm{~N}_{2}\right)$ and (2) hypoxia 
Table 1 Clinicopathological features and expression of HIF- $1 \alpha$ and P-gp in human colon carcinoma tissue

\begin{tabular}{|c|c|c|c|c|c|}
\hline \multirow[t]{2}{*}{ Clinicopathological findings } & \multirow[t]{2}{*}{$\begin{array}{l}\text { Total } \\
\text { (Paraffin-embedded } \\
\text { tissues) }\end{array}$} & $\begin{array}{l}\text { HIF-1 } \alpha(+) / \\
\text { P-gp (+) }\end{array}$ & $\begin{array}{l}\text { HIF-1 } \alpha(+) / \\
\text { P-gp (-) }\end{array}$ & $\begin{array}{l}\text { HIF- } 1 \alpha(-) / \\
\text { P-gp }(+)\end{array}$ & $\begin{array}{l}\text { HIF- } 1 \alpha(-) / \\
\text { P-gp }(-)\end{array}$ \\
\hline & & \multicolumn{4}{|l|}{$(\mathrm{n}, \%)$} \\
\hline All & 58 & $24(41.4)$ & $10(17.2)$ & $3(5.2)$ & $21(36.2)$ \\
\hline Gender & $P=0.513^{*}$ & & & & \\
\hline Male & 30 & $12(40.0)$ & $7(23.3)$ & $2(6.7)$ & $9(30.0)$ \\
\hline Female & 28 & $12(42.9)$ & $3(10.7)$ & $1(3.5)$ & $12(42.9)$ \\
\hline Age & $P=0.753^{*}$ & & & & \\
\hline$<60$ & 25 & $9(36.0)$ & $4(16.0)$ & $1(4.0)$ & $11(44.0)$ \\
\hline$\geq 60$ & 33 & $15(45.5)$ & $6(22.0)$ & $2(6.1)$ & $10(30.4)$ \\
\hline Location & $P=0.398^{*}$ & & & & \\
\hline Left hemicolon & 30 & $15(50.0)$ & $5(16.7)$ & $2(6.7)$ & $8(26.6)$ \\
\hline Right hemicolon & 28 & $9(32.1)$ & $5(17.9)$ & $1(3.6)$ & $13(46.4)$ \\
\hline Differentation degree & $P=0.103^{*}$ & & & & \\
\hline Well \& Moderately differentiated & 43 & $17(39.5)$ & $5(11.6)$ & $2(4.7)$ & $19(44.2)$ \\
\hline Poorly differentiated & 15 & $7(46.7)$ & $5(33.3)$ & $1(6.7)$ & $2(13.3)$ \\
\hline Dukes' stage & $P=0.003^{*}$ & & & & \\
\hline A \& B & 38 & 12 (31.6) & $4(10.5)$ & $2(5.3)$ & $20(52.6)$ \\
\hline$C \& D$ & 20 & $12(55.0)$ & $6(30.0)$ & $1(10.0)$ & $1(5.0)$ \\
\hline Lymphatic invasion & $P=0.005^{*}$ & & & & \\
\hline Positive & 19 & $11(57.9)$ & $6(31.5)$ & $1(5.3)$ & $1(5.3)$ \\
\hline Negative & 39 & $13(33.3)$ & $4(10.3)$ & $2(5.1)$ & $20(51.3)$ \\
\hline
\end{tabular}

$* \chi^{2} P$ value

group, cultured under hypoxic conditions $\left(1 \% \mathrm{O}_{2}, 5 \% \mathrm{CO}_{2}\right.$, and $94 \% \mathrm{~N}_{2}$ ).

\section{Immunohistochemistry}

IHC was performed on 4- $\mu$ m-thick sections of formalinfixed (10\%), paraffin-embedded tissues. A commercial streptavidin/peroxidase (SP) kit (Beijing ZhongShan Golden Bridge Biotech CO., LTD, China) was used for IHC. Sections were deparaffinaged in xylene, taken through ethanol and microwaved with target retrieval solution (citrate sodium buffer) for $20 \mathrm{~min}$. Then sections were incubated with $3 \%$ hydrogen peroxide to block endogenous peroxidase activity. Subsequent steps were performed according to the manufacturer's instructions. The sections were respectively incubated with anti-HIF$1 \alpha$ and anti-P-gp-specific rabbit polyclonal antibodies (both at a working dilution of 1:100; Wuhan Boster Biological Project CO., LTD, China). The primary antibody reaction was carried out at $4{ }^{\circ} \mathrm{C}$ overnight. For a negative control, sections were incubated with phosphate-buffered saline (PBS; $0.01 \mathrm{~mol} / \mathrm{l}, \mathrm{pH} 7.4$ ) instead of the primary antibodies. 3,3'-diaminobenzidine (DAB)/hydrogen peroxide (Beijing ZhongShan Golden Bridge Biotech CO., LTD, China) was used to detect antigen-antibody binding, and slides were counterstained with hematoxylin. Clear brown-yellow staining was restricted to the cytoplasm, nuclei or cell membrane that indicated a positive result of HIF- $1 \alpha$ or P-gp expression.

Double-label immunofluorescence

Double-label immunofluorescence staining was performed on 7-10- $\mu \mathrm{m}$-thick sections of paraformaldehyde-fixed (4\%), OTC-embedded, frozen-sliced tissues. Sections were thoroughly washed in PBS and incubated with 1\% BSA for $30 \mathrm{~min}$. Then, sections were incubated with first primary antibody MDR1 $(1: 100)$ for $8 \mathrm{~h}$ at $4^{\circ} \mathrm{C}$ and Cy3-labeled goat anti-rabbit IgG (1:100; Wuhan Boster Biological Project CO., LTD, China) for $1 \mathrm{~h}$ at $25^{\circ} \mathrm{C}$ by turns. After being washed in PBS and blocked with 1\% BSA for $30 \mathrm{~min}$, the secondary primary antibody HIF- $1 \alpha(1: 100)$ and FITClabeled goat anti-rabbit IgG (1:100) (Wuhan Boster Biological Project CO., LTD, China) were added to the sections in order for $8 \mathrm{~h}$ at $4^{\circ} \mathrm{C}$ and $1 \mathrm{~h}$ at $25^{\circ} \mathrm{C}$, respectively. The protein expression was observed by fluorescence microscope after being counterstained with 4',6-diamidino-2-phenylindole 2HCI (DAPI) and mounted with water-solubility mounting agents. For a negative control, sections were incubated with PBS instead of the primary antibodies. 
Immunocytochemistry

After cell cultures under normoxia or hypoxia, the cover slips that covered the monolayer cells were washed with PBS and fixed for $30 \mathrm{~min}$ at room temperature with $4 \%$ paraformaldehyde. SP immunocytochemical techniques were used to detect the expression of HIF- $1 \alpha$ and P-gp. The working dilution of both antibodies was 1:100. Subsequent steps were performed according to the manufacturer's instructions. For a negative control, PBS was used as the primary antibody instead of HIF- $1 \alpha$ protein, and P-gp expression was analyzed by a cellular image analysis system (Image-Pro Plus 4.5, Media Cybernetics, Inc., USA). Expression levels of protein were quantified using the mean optical density value of the positive signals.

\section{Reverse transcriptase-polymerase chain reaction analysis (RT-PCR)}

Total RNA was extracted respectively from HCT-116, HT-29, LoVo, and SW480 cells with TRIZOL (Shanghai Sangon Biological Engineering Technology \& Services Co., Ltd, China). Two oligomers of primers were synthesized on the basis of the designed sequences (Primer Premier 5.0). HIF- $1 \alpha$ mRNA was amplified by using 5'-CTTCTGGATGCTGGTGATT-3' as the forward primer

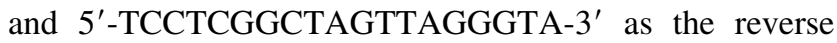
primer. MDR1 mRNA was amplified by using 5'-GGAGG AGCAAAGAAGAAG-3' as the forward primer and $5^{\prime}$-AATGTAAGCAGCAACCAG-3' as the reverse primer. The primers of glyceraldehyde 3-phosphate dehydrogenase (GAPDH) were synthesized according to previous studies (F, 5'-CAAATTCCATGGCACCGTCA-3' and R, 5'-GGA GTGGGTGTCGCTGTTGA-3'). GAPDH was used as an internal control. The primer pair amplified a 324-base pair (bp) fragment as HIF-1 $\alpha$, a 369-bp fragment as MDR1, and a 715-bp fragment as GAPDH. All the primers were synthesized by Shanghai Sangon Biological Engineering Technology \& Services Co., Ltd. RT-PCR was performed with the isolated RNA and the oligomers as templates and primers, respectively by using Takara RT-PCR V3.0 Kit. For HIF- $1 \alpha$ and MDR1, the cDNA was amplified with 35 cycles of denaturation for $2 \mathrm{~min}$ at $94^{\circ} \mathrm{C}$, annealing for $30 \mathrm{~s}$ at $61.5^{\circ} \mathrm{C}$, and extension for $30 \mathrm{~s}$ at $72^{\circ} \mathrm{C}$. For GAPDH, the cDNA was amplified with 35 cycles of denaturation for $5 \mathrm{~min}$ at $94^{\circ} \mathrm{C}$, annealing for $45 \mathrm{~s}$ at $57^{\circ} \mathrm{C}$, and extension for $45 \mathrm{~s}$ at $72^{\circ} \mathrm{C}$. After amplification, products were loaded onto a $1.5 \%$ agarose gel in $1 \times$ Tris $\mathrm{Cl}$-acetate-ethylene diamine tetraacetic acid (EDTA; TAE) buffer and the specific bands were visualized with ethidium bromide (EB) and photographed under ultraviolet light. RT-PCR without reverse transcriptase yielded no specific bands. HIF- $1 \alpha$, MDR1, and GAPDH mRNA levels were quantified with the aid of computer software (Quantity One 4.4.0, BIORAD, USA). For semi-quantitative analysis, HIF- $1 \alpha$ and MDR1 PCR products were normalized to GAPDH by the mean optical density value of the specific bands.

\section{Statistical analysis}

All results were expressed as mean \pm standard deviation (SD). Statistical analysis, including the Chi-square test, correlated Spearman test, one-way ANOVA test, and $t$ test, were carried out using the software package SPSS 13.0. The significance level was set at $5 \%$ for each analysis.

\section{Results}

Expression of HIF- $1 \alpha$ and P-gp in human colon carcinoma tissue

HIF- $1 \alpha$ protein expression was predominantly localized in the cytoplasm of tumor cells (Fig. 1a), part of in nuclei

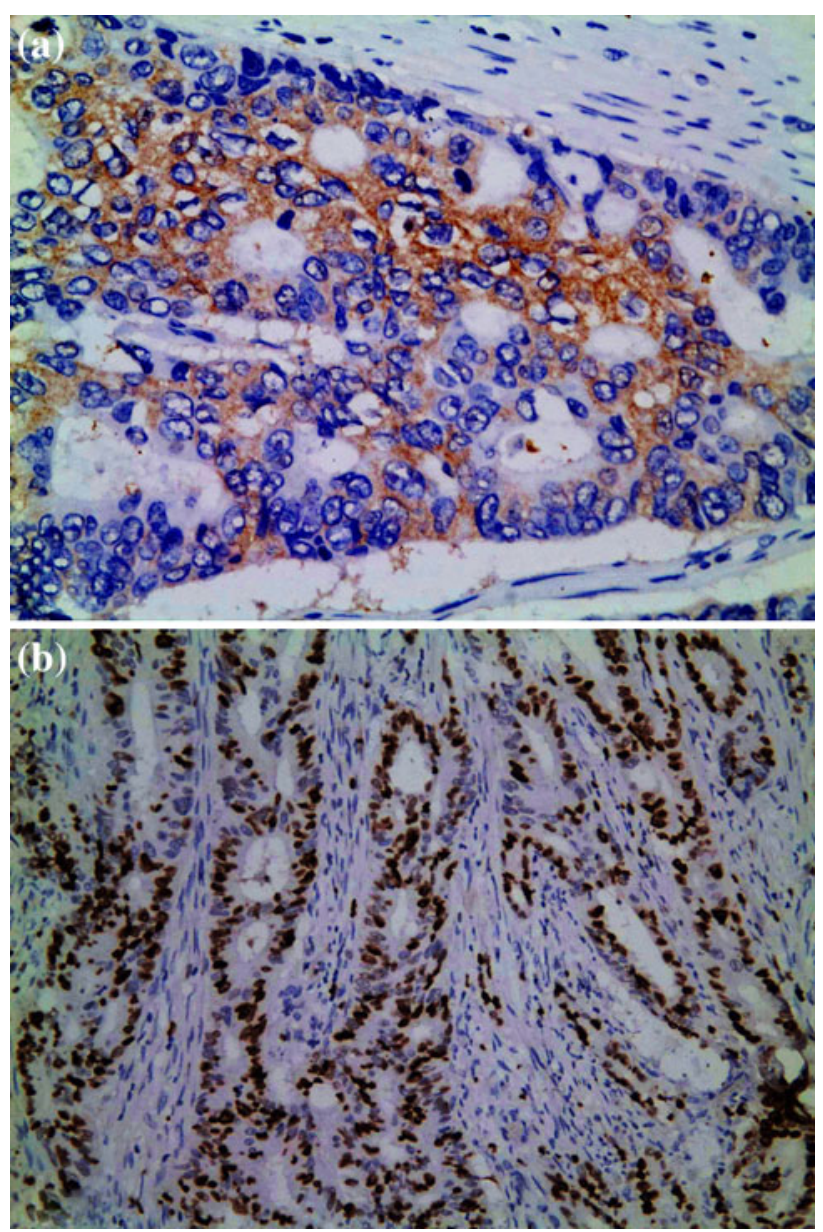

Fig. 1 IHC staining for HIF- $1 \alpha$ in human colon carcinoma tissue. a Strong HIF- $1 \alpha$ immunoreactivity in cytoplasm of tumor cells $(\times 400)$. b HIF- $1 \alpha$ immunoreactivity in nuclei of tumor cells $(\times 200)$ 
(Fig. 1b), especially in the margin of tumor necrotic and infiltrating regions. P-gp expression was mainly localized in cytoplasm and cytomembrane of tumor cells (Fig. 2a, b). According to the 58 tissue specimens, the statistical analysis of HIF- $1 \alpha$ and P-gp expression was as follows (Table 1). Of the 58 paraffin-embedded cases, $24(41.4 \%)$ cases were positive expression with HIF- $1 \alpha(+) / \mathrm{P}-\mathrm{gp}(+)$, $10(17.2 \%)$ cases were HIF- $1 \alpha(+) / \mathrm{P}-\mathrm{gp}(-), 3(5.2 \%)$ cases were HIF- $1 \alpha(-) / \mathrm{P}$-gp $(+)$, and $21(36.2 \%)$ cases were HIF- $1 \alpha(-) / \mathrm{P}-\mathrm{gp}(-)$. Among these four groups, significant differences were observed for Dukes' stage [HIF- $1 \alpha(+) / \mathrm{P}-\mathrm{gp}(+)$, HIF- $1 \alpha(+) / \mathrm{P}-\mathrm{gp}(-)$, and HIF- $1 \alpha$ $(-) / \mathrm{P}-\mathrm{gp}(+)$ cases more likely to have a higher grade stage, $P=0.003]$ and lymphatic invasion $[\mathrm{HIF}-1 \alpha(+) /$ P-gp (+) and HIF-1 $\alpha(-) / \mathrm{P}-g p(+)$ cases more likely to exist lymphatic invasion, $P=0.005]$. Overall, no differences of HIF- $1 \alpha$ and P-gp expression were noted in the gender, age, location, and differentation degree among these four groups $(P>0.05)$.
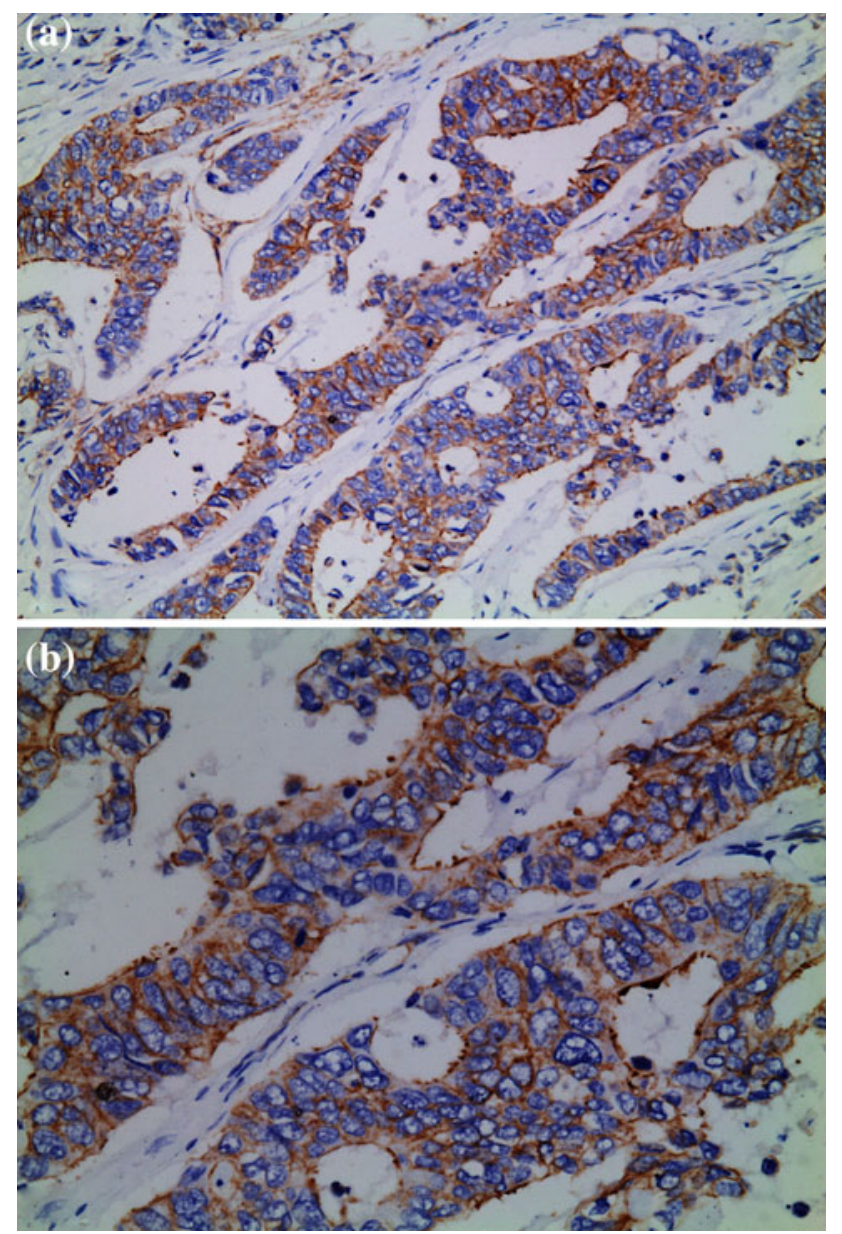

Fig. 2 IHC staining for P-gp in human colon carcinoma tissue. Strong $\mathrm{P}$-gp immunoreactivity in cytoplasm and cytomembrane of tumor cells. a, $(\times 200)$; b, $(\times 400)$
Table 2 Association analysis between HIF- $1 \alpha$ and P-gp expression in human colon carcinoma tissue

\begin{tabular}{llcc}
\hline $\begin{array}{l}\text { P-gp } \\
\text { (No. of cases) }\end{array}$ & \multicolumn{2}{l}{ HIF-1 $\alpha$ (No. of cases) } & Total \\
\cline { 2 - 3 } & Positive & Negative & \\
\hline Positive & 24 & 3 & 27 \\
Negative & 10 & 21 & 31 \\
Total & 34 & 24 & 58 \\
\hline
\end{tabular}

$R=0.574, P<0.01$

Correlation between HIF- $1 \alpha$ and P-gp expressions

The Spearman analysis showed that the expression level of HIF- $1 \alpha$ was significantly associated with P-gp expression $(r=0.574, P<0.01$; Table 2).

Coexpression of HIF- $1 \alpha$ and P-gp in human colon carcinoma tissue by double-label immunofluorescence staining

In the eight fresh resected specimens, HIF- $1 \alpha$ expression was chiefly localized in cytoplasm of tumor cells, also part in nuclei by using double-label immunofluorescence staining method (Fig. 3a, d, green fluorescence). Likewise, P-gp expression was chiefly observed in cytoplasma and membrane of tumor cells (Fig. 3b, e, red fluorescence), and coexpression phenomenon was also found in colon carcinoma tissue (Fig. 3c, f, yellow).

Expression of HIF- $1 \alpha$ and P-gp in colon carcinoma cells after normoxic and hypoxic incubation

In the four experimental cell lines (HCT-116, HT-29, LoVo, and SW480), the expression of HIF- $1 \alpha$ and P-gp were both observed, strongly expressed in the hypoxic group, but weakly or negatively expressed in the normoxic group. HIF- $1 \alpha$ immunoreactivity was predominantly located in cytoplasm, most of them were found around the nuclei and part in nuclei (Fig. $4 \mathrm{a}-\mathrm{h}$ ). The expression of $\mathrm{P}$-gp was mainly found in cell cytoplasm and a bit in cytomembrane (Fig. $4 i-p)$ ). Expression of HIF- $1 \alpha$ protein and $\mathrm{P}$-gp was markedly enhanced after culture under hypoxic conditions for $24 \mathrm{~h}$. According to the expression differences between the same cell line, image analysis revealed that mean optical density representing HIF-1 $\alpha$ or P-gp expression in the hypoxia group was significantly higher than that in the normoxia group $(P<0.01)$ (Table 3$)$. However, no significant differences of HIF- $1 \alpha$ or P-gp expression were found among each cell line under the same cultural conditions $(P>0.05)$.

HIF- $1 \alpha$ and MDR 1 mRNA expression in colon carcinoma cells under normoxic and hypoxic conditions

RT-PCR revealed that HIF- $1 \alpha$ and MDR1 mRNA was strongly expressed in the hypoxia group of the four types of cells, but all weakly expressed in the normoxia group (Fig. 5). As far as the same target gene and cell were 
Fig. 3 Double-label immunofluorescence staining for HIF- $1 \alpha$ and P-gp in human colon carcinoma tissues. a-c, $(\times 200), \mathbf{d}-\mathbf{f}$, $(\times 400)$. (green shows HIF- $1 \alpha$, red shows P-gp, yellow shows coexpression)
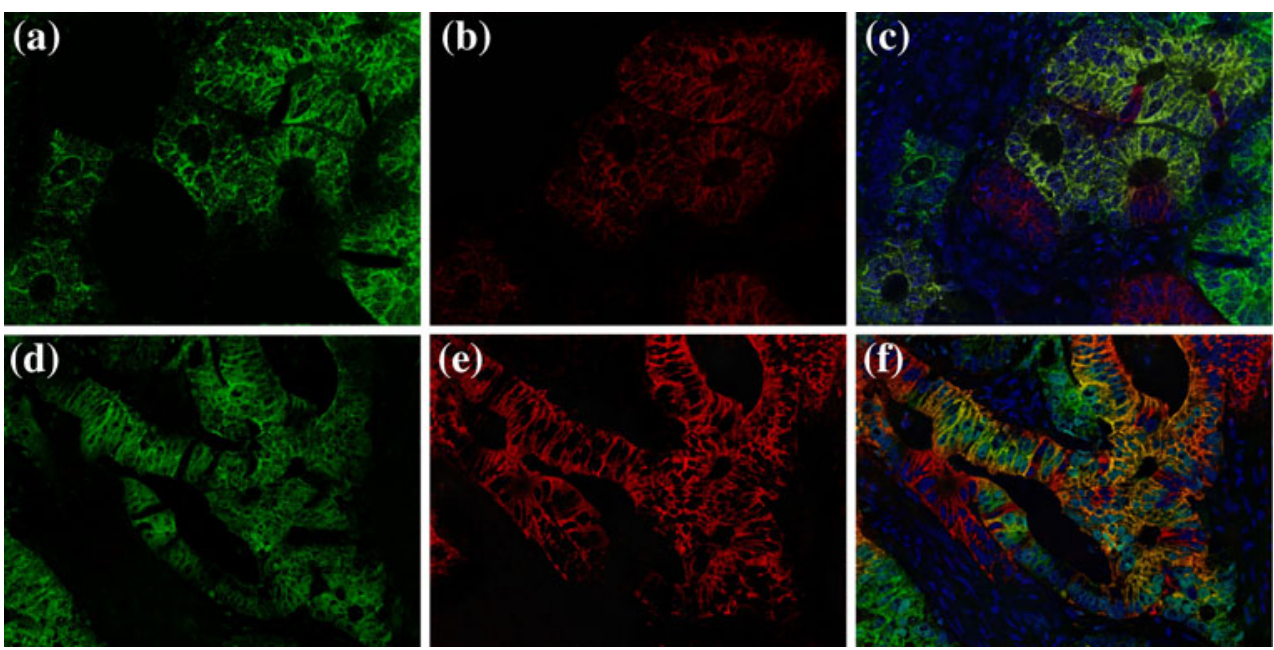

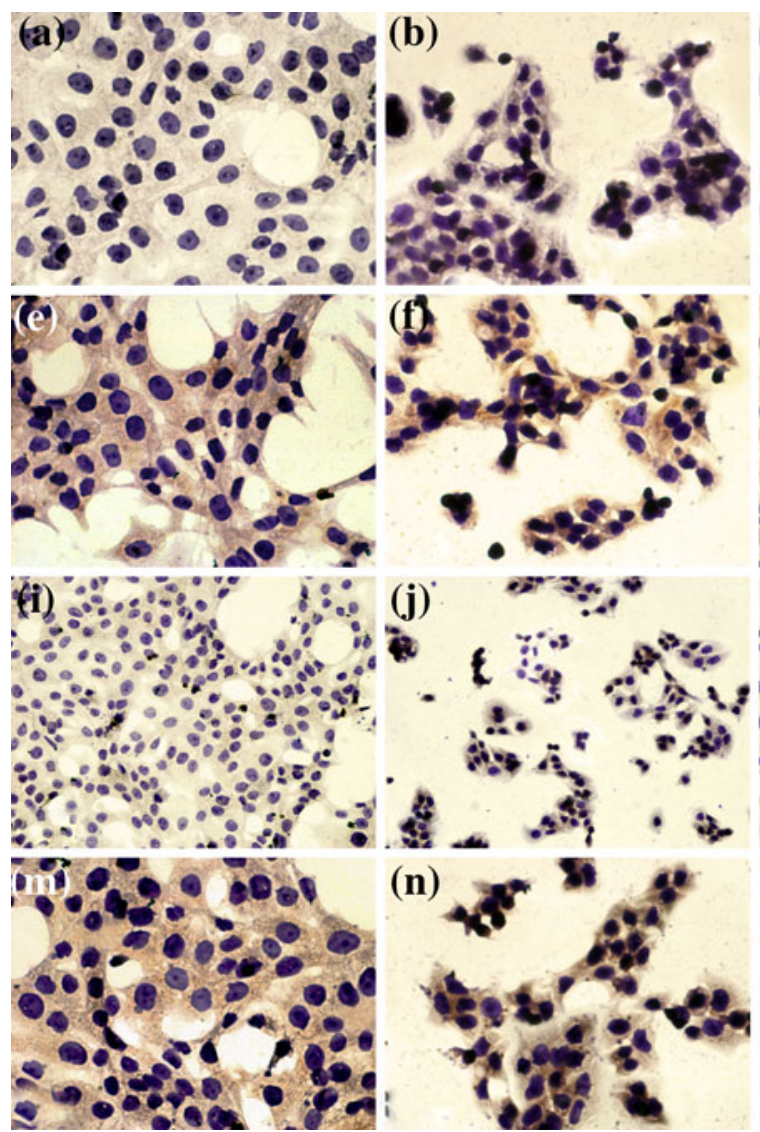

Fig. 4 Immunocytochemical staining for HIF-1 $\alpha$ and P-gp in human colon carcinoma cells under normoxia and hypoxia conditions. Very weak HIF- $1 \alpha$ and P-gp expression were detected in the four cells in normoxia, (a-c) and (i-l). Strong HIF- $1 \alpha$ and P-gp immunoreactivity

concerned, optical density representing HIF- $1 \alpha$ or MDR 1 mRNA expression levels was significantly higher in the hypoxia group than that in the normoxia group $(P<0.01$; Table 4; Fig. 6). Likewise, no significant differences of
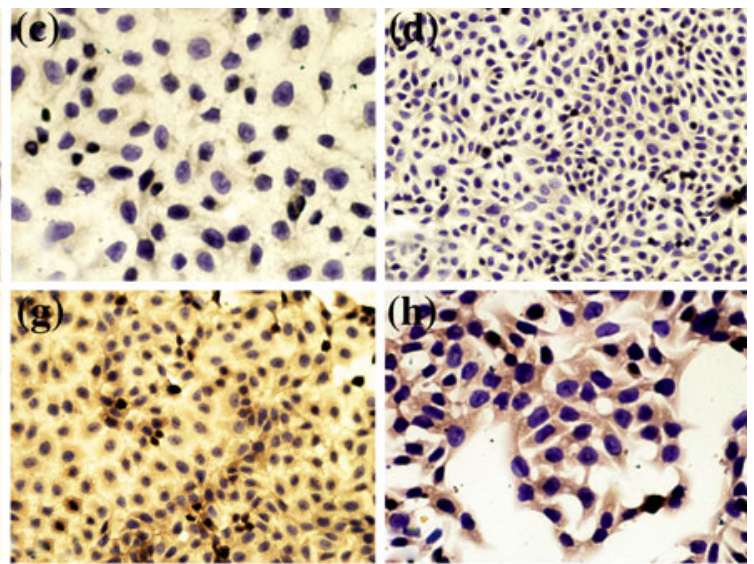

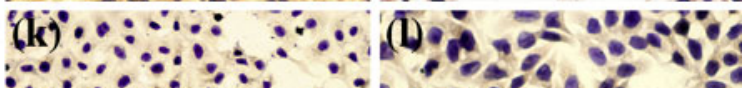
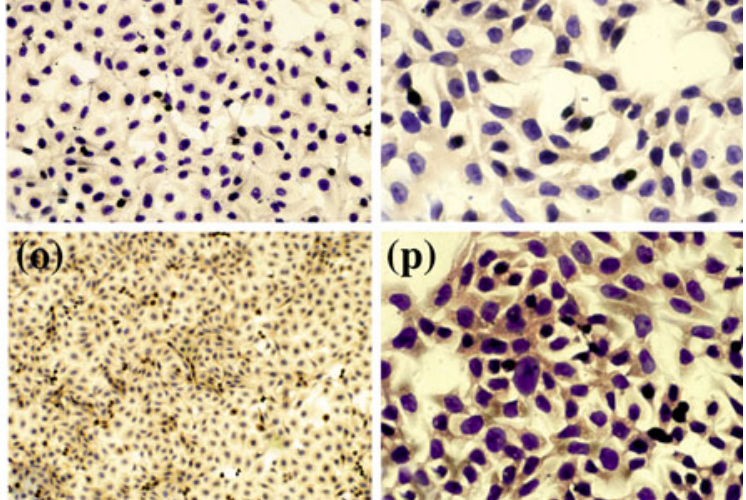

in cytoplasm of tumor cells was observed after hypoxia culture for $24 \mathrm{~h},(\mathbf{e})-(\mathbf{h})$ and $(\mathbf{m})-(\mathbf{p})$. a-h shows HIF- $1 \alpha, \mathbf{i}-\mathbf{p}$ shows P-gp. HCT-116: first vertical line; HT-29: second vertical line; LoVo: third vertical line; SW480: last vertical line. d, i, j, k, o: $(\times 200)$; else: $(\times 400)$

HIF- $1 \alpha$ or MDR1 mRNA expression were found among each cell line under the same $\mathrm{PaO}_{2}$ cultural conditions $(P>0.05)$. Obviously, RT-PCR analysis was totally consistent with the results of the immunocytochemistry assays. 
Table 3 Expression levels of HIF-1 $\alpha$ and P-gp under normoxic and hypoxic conditions in human colon carcinoma cells

\begin{tabular}{llllll}
\hline Experimental group & & HCT-116 & HT-29 & LoVo & SW480 \\
\hline HIF-1 $\alpha$ & N & $0.1501 \pm 0.0062$ & $0.1482 \pm 0.0041$ & $0.1527 \pm 0.0045$ & $0.1573 \pm 0.0037$ \\
& H & $0.3320 \pm 0.0071^{*}$ & $0.3309 \pm 0.0053^{*}$ & $0.3394 \pm 0.0109^{*}$ & $0.3376 \pm 0.0084^{*}$ \\
P-gp & N & $0.1218 \pm 0.0043$ & $0.1197 \pm 0.0038$ & $0.1203 \pm 0.0033$ & $0.1253 \pm 0.0052$ \\
& H & $0.2854 \pm 0.0078^{* *}$ & $0.2757 \pm 0.0068^{* *}$ & $0.2892 \pm 0.0041^{* *}$ & $0.2884 \pm 0.0036^{* *}$ \\
\hline
\end{tabular}

Note $N$, Normoxia; $H$ Hypoxia

${ }^{*} P<0.01$, analysis of HIF- $1 \alpha$ expression of the same type of cell under normoxic and hypoxic culture conditions, compared with normoxia group;

${ }^{* *} P<0.01$, analysis of $\mathrm{P}$-gp expression of the same type of cell under normoxic and hypoxic culture conditions, compared with normoxia group

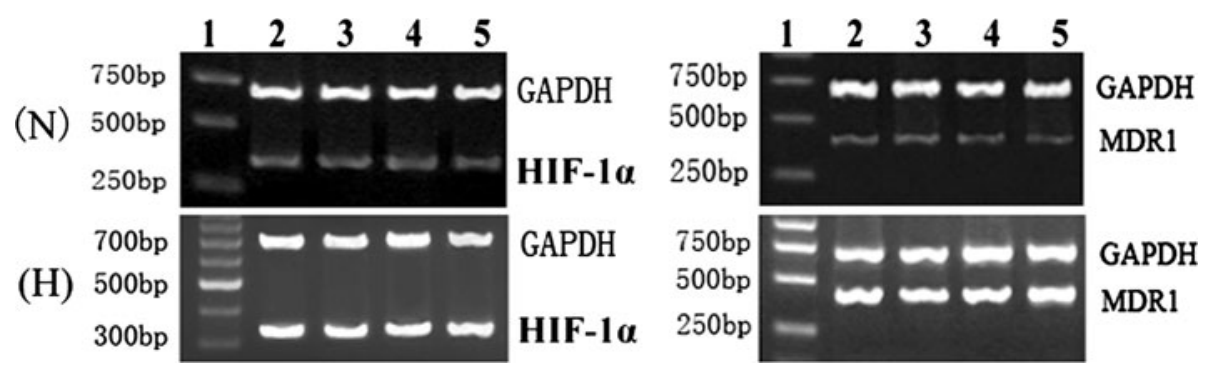

Fig. 5 Expression of HIF-1 $\alpha$ and MDR1 mRNA levels in cells under different conditions as determined by RT-PCR. lane1: marker, lane2: HCT-116, lane3: HT-29, lane4: LoVo, lane5: SW480 GAPDH is included as an internal control. ( $N$ normoxia; $H$ hypoxia treatment for 24 h)

Table 4 Expression levels of HIF-1 $\alpha$ and MDR1 mRNA under normoxic and hypoxic conditions in human colon carcinoma cells

\begin{tabular}{llllll}
\hline Experimental group & & HCT-116 & HT-29 & LoVo & SW480 \\
\hline $\mathrm{A}_{\mathrm{HIF-1 \alpha}} / \mathrm{A}_{\mathrm{GAPDH}}$ & $\mathrm{N}$ & $0.4901 \pm 0.0472$ & $0.4872 \pm 0.0592$ & $0.4824 \pm 0.0325$ & $0.4941 \pm 0.0687$ \\
& $\mathrm{H}$ & $0.9989 \pm 0.0312^{*}$ & $0.9968 \pm 0.0618^{*}$ & $0.9978 \pm 0.0721^{*}$ & $0.9944 \pm 0.0576^{*}$ \\
$\mathrm{~A}_{\mathrm{MDR} 1} / \mathrm{A}_{\mathrm{GAPDH}}$ & $\mathrm{N}$ & $0.3932 \pm 0.0295$ & $0.3952 \pm 0.0793$ & $0.3937 \pm 0.0671$ & $0.3961 \pm 0.0990$ \\
& $\mathrm{H}$ & $0.9909 \pm 0.0562^{* *}$ & $0.9954 \pm 0.0388^{* *}$ & $0.9972 \pm 0.0422^{* *}$ & $0.9934 \pm 0.0764^{* *}$ \\
\hline
\end{tabular}

Note $N$ Normoxia; $H$ Hypoxia

${ }^{*} P<0.01$, analysis of HIF- $1 \alpha$ mRNA expression of the same type of cell under normoxic and hypoxic culture conditions, compared with normoxia group; ${ }^{* *} P<0.01$, analysis of MDR1 mRNA expression of the same type of cell under normoxic and hypoxic culture conditions, compared with normoxia group

\section{Discussion}

Chemotherapy is one of alternatives for treating cancers, but a main obstacle in the development of effective cancer chemotherapy is MDR phenotype, which is one of the crucial reasons leading to the failure of treatment. Overexpression of P-gp and multidrug resistance-associated protein (MRP) are generally believed to be the mechanism responsible for MDR of tumor cells. Hypoxia is a common feature of many malignant tumors. The physiology and biochemistry of tumor cells changes to adapt hypoxia. HIF-1 is a key factor in altering the biological characteristics of tumors (Mabjeesh and Amir 2007; Jensen et al. 2006; Nagle and Zhou 2006). Many studies indicated that hypoxia helped to improve chemotherapy and radiotherapy resistance of tumor (Magnon et al. 2007; O’Donnell et al. 2006; Schnitzer et al. 2006; Sullivan et al. 2008). Better understanding the influence of tumor MDR by hypoxia will help improve the effect of chemotherapy. It has been reported that HIF- $1 \alpha$ protein was overexpressed in multiple types of human cancer, including lung, breast, prostate, gastric, and colon carcinomas, even in preneoplastic and premalignant lesions, such as colonic adenoma, breast ductal carcinoma in situ, and prostate intraepithelial neoplasia (Giatromanolaki et al. 2001; Liu et al. 2008; Schindl et al. 2002; Welsh et al. 2002). More importantly, Birner et al. (Birner et al. 2000) found that the overexpression of HIF- $1 \alpha$ is an important marker in precancerous lesion such as early-stage cervical cancer, cervical intra-epithelial neoplasia III, and earlystage lymph node-negative breast cancer.

Hypoxia is well known to induce resistance to drugs and radiation in solid tumors (Piret et al. 2006; Wu et al. 2007) 
Fig. 6 Analysis of mRNA expression under normoxic and hypoxic conditions in human colon carcinoma cells, a HIF- $1 \alpha$, b MDR $1 ; N$ normoxia;

$H$ hypoxia; $A$ Absorbance
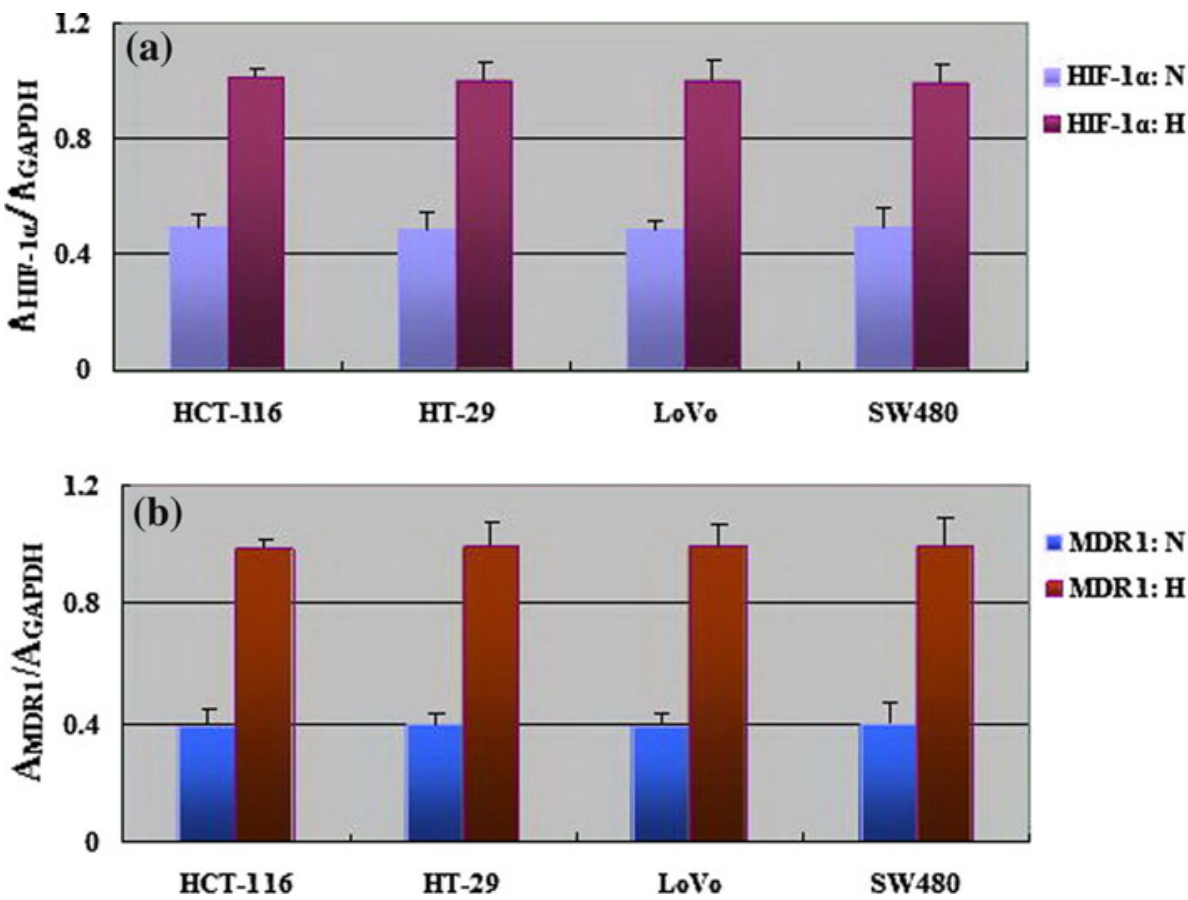

as well as in multicellular tumor spheroids (Wartenberg et al. 2001a, b). The reason that hypoxia contributes to drug resistance in anticancer therapy has not yet been established. It has been demonstrated that hypoxia reduces the expression of DNA topoisomerase II $\alpha$, which renders cells resistant to topoisomerase II-targeted drugs such as etoposide and doxorubicin (Ogiso et al. 2000). Furthermore, glutathione $S$-transferase pi (GST-pi), which has been demonstrated to be involved in the MDR phenotype, has recently been shown to be up-regulated by hypoxia in several cancer cell lines. A correlation between P-gp and GST-pi has been reported (Weissenberger et al. 2000); this report indicated that there may be a common mechanism for regulating the expression of drug resistance-related proteins. Graeber TG et al. (Graeber et al. 1996) have revealed that a number of factors associated either directly or indirectly with tumor hypoxia contributed to resistance to anticancer drugs in a solid tumor in vivo. Cells in hypoxic regions of a tumor stop or slow their rate of progression through the cell cycle. This effect is the result of increased expression of specific proteins, e.g., the tumor suppressor p53 and the cyclin-dependent kinase inhibitor p27Kip1 (Gardner et al. 2001; Wenger et al. 1998), which are induced under hypoxic conditions. Because most anticancer drugs are more effective against rapidly proliferating cells than nonproliferating cells, this slowing of cell proliferation will lead to increased chemoresistance. Another way by which hypoxia may contribute to drug resistance is through reduced generation of endogenous nitric oxide (NO) under hypoxic conditions, as recently evidenced in Matthews and Yu et al. (Matthews et al. 2001; Yu et al. 2006). These authors demonstrated that pharmacological inhibition of NO generation abolished the drug resistance observed after hypoxic incubation of tumor cells.

In addition, reactive oxygen species (ROS; e.g., $\mathrm{H}_{2} \mathrm{O}_{2}$ ) have previously been shown to increase degradation of HIF- $1 \alpha$ via the ubiquitin-proteasome pathway. Endogenous generation of ROS is a common feature of tumor cells and may regulate neoplastic cell growth. Recent study demonstrated that expression of P-gp is down-regulated on elevation of the intracellular redox state (Wartenberg et al. 2000, 2001a, b). Wartenberg et al. (Wartenberg et al. 2003) found that a pronounced up-regulation of HIF- $1 \alpha$ as well as P-gp was achieved by cultivation of small tumor spheroids under low oxygen pressure (physiological hypoxia) as well as after treatment with $\mathrm{CoCl}_{2}$, which are known to induce chemical hypoxia.

In this study, we observed and analyzed the expression and relationship of HIF- $1 \alpha$ and P-gp in 58 specimens by using IHC. The expression of HIF-1 $\alpha$ protein and P-gp were significantly higher in tissue samples classified as Dukes' stages $\mathrm{C}$ or $\mathrm{D}$, involving lymph node metastasis, than in samples classified as Dukes' stages A or B, indicating that HIF- $1 \alpha$ was involved in tumor invasion and metastasis. Thus, we believe that HIF- $1 \alpha$ represents a biomarker for premalignant lesions and tumor progression that warrants clinical surveillance. Association analysis displays that HIF- $1 \alpha$ protein expression was significantly correlated with P-gp expression $(P<0.01)$. Moreover, double-label immunofluorescence demonstrates that coexpression of HIF- $1 \alpha$ and P-gp dose exist in human colon carcinoma tissue. IHC studies of HIF- $1 \alpha$ in human tissues have been 
reported recently (Zhong et al. 1999). Mixed nuclear and cytoplasmic staining patterns were observed in these studies. HIF- $1 \alpha$ expression was absent in most normal tissues, and the staining patterns were variable in each organ. In our study, HIF- $1 \alpha$ immunoreactivity was localized in the cytoplasm and/or nuclei of colon carcinoma cells. The reason for these differences in staining patterns is unknown. We observed two distinct patterns of HIF- $1 \alpha$ immunostaining. One pattern was heterogeneous and was detected only in viable tumor cells surrounding the area of necrosis, whereas the other pattern was diffuse and homogeneous. The heterogeneous staining may have been the result of hypoxia, whereas the homogeneous pattern may have been due to regulatory modes other than hypoxia. Expression of HIF- $1 \alpha$ is enhanced by genetic alterations in tumor suppressor genes (p53, PTEN) and oncogenes (v-src, H-ras) and by the induction of several growth factors (insulin-like growth factor (IGF)-1 and IGF-2, basic fibroblast growth factor (bFGF), and epidermal growth factor (EGF)). It is possible that the homogeneous HIF- $1 \alpha$ immunostaining pattern in colon carcinoma was associated with these factors, at least in part (Kimura et al. 2004). Additional studies are needed to elucidate these associations.

For examining the expression changes of HIF- $1 \alpha$ and $\mathrm{P}$-gp in hypoxia, we cultured human colon carcinoma cells (HCT-116, HT-29, LoVo, and SW480) respectively under normoxic and hypoxic conditions, and immunochemically detected the expression of them. Our results showed that HIF- $1 \alpha$ mainly existed in cytoplasm and nuclei. P-gp, as a transmembrane protein, mainly exists in the cytomembrane and cytoplasm of the four types of cells. We found that the expression of HIF- $1 \alpha$ and P-gp were positively correlated. The expression of HIF- $1 \alpha$ and P-gp in the experimental cells were both up-regulated after incubation under hypoxia for $24 \mathrm{~h}$, while under the normal $\mathrm{PaO}_{2}$ the expression of HIF- $1 \alpha$ was just quite weakly detected, and little P-gp immunoreactivity was observed, respectively with the differences being statistically significant. Also, the consistent data results with immunocytochemistry were further given by using RT-PCR. The high expression of P-gp may increase the stability of the tumor cells under hypoxic conditions. The $\mathrm{PaO}_{2}$ of body organs (except marrow and cartilage) is generally normal, so the HIF- $1 \alpha$ may serve as a new target for the molecular treatment of tumor. Combining with the results of tissue specimens and other reported data, it suggests that hypoxia induce the overexpression of HIF- $1 \alpha$ and MDR1/P-gp in colon carcinoma, and HIF- $1 \alpha$ expression may be associated with the gene MDR1 (P-gp) and interactively involved in the occurrence of tumor multidrug resistance.

The data of the recent study demonstrate that intrinsic expression of P-gp in multicellular tumor spheroids is regulated by hypoxic conditions in the depth of the tissue and requires the presence of HIF- $1 \alpha$. However, it is currently unknown how HIF- $1 \alpha$ may regulate the expression of P-gp. The sequenced MDR1 gene coding for P-gp was cloned several years ago (Roninson et al. 1984, 1986) and does not contain any HIF-1 binding sites, which suggests that P-gp is not under the direct control of HIF-1 but may be indirectly regulated, e.g., by transactivation. However, it cannot be excluded that the hypoxia response elements of genes binding to HIF-1 are located at some distance from the coding region of the gene. It was recently demonstrated that induction of the murine MDR1 gene by the polycyclic aromatic hydrocarbon 3-methylcholanthrene requires a functional heterodimer of the aromatic hydrocarbon receptor and ARNT as well as activation of the tumor suppressor and transcription factor $\mathrm{p} 53$. This finding indicates that under the experimental conditions used in the present study, i.e., under hypoxia, MDR1 expression may require a functional HIF-1 $\alpha /$ ARNT heterodimer and presumably activation of $\mathrm{p} 53$. In this respect, it has been convincingly shown that mutant p53 up-regulates the MDR1 gene via Ets-1 (Sampath et al. 2001), which is a transcription factor under the control of HIF-1 and up-regulated under hypoxic conditions (Oikawa et al. 2001). Furthermore, HIF-1 $\alpha$ may regulate MDR1 expression via protein kinase A-dependent activation of cAMP-positive factors, which were previously shown to exert a positive regulatory effect on MDR1 transcription. The cAMP response element binding factor (CREB) promotes cellular gene expression, after its phosphorylation at Ser133, via recruitment of the coactivator paralogs CREB binding protein (CBP) and p300. Thus, it was hypothesized that $\mathrm{p} 53$ and HIF- $1 \alpha$ functions are differently regulated by CBP and may independently activate transcription, e.g., transcription of the MDR1 gene. Alternatively, a convergence of CBP-dependent, HIF- $1 \alpha$ - and p53-mediated pathways may be required for activation of the MDR1 gene and establishment of the MDR phenotype.

In conclusion, we showed that HIF- $1 \alpha$ expression is significantly associated with MDR1/P-gp expression in human colon carcinoma. The dissection of the multistep regulation of MDR1 gene under hypoxic conditions is just beginning. Further studies will add to the understanding of how HIF- $1 \alpha$ was involved in multidrug resistance with MDR1 gene in malignant tumors and will help find a novel strategy for the reversal of MDR.

Acknowledgments The authors sincerely acknowledge Dr. Feng Mei (Department of Histology and Embryology, College of Medicine, Third Military Medical University) for the technical supports of frozen sections.

Conflict of interest statement We confirm that all authors fulfill all conditions required for authorship. We also confirm that there is no potential conflict of interest or financial dependence regarding this publication, as described in the Instruction for Authors. All authors have read and approved the manuscript. 
Open Access This article is distributed under the terms of the Creative Commons Attribution Noncommercial License which permits any noncommercial use, distribution, and reproduction in any medium, provided the original author(s) and source are credited.

\section{References}

Birner P, Schindl M, Obermair A, Plank C, Breitenecker G, Oberhuber $\mathrm{G}$ (2000) Overexpression of hypoxia-inducible factor 1alpha is a marker for an unfavorable prognosis in early-stage invasive cervical cancer. Cancer Res 60:4693-4696

Durand RE, Raleigh JA (1998) Identification of nonproliferating but viable hypoxic tumor cells in vivo. Cancer Res 58:3547-3550

Fang J, Zhou Q, Liu LZ, Xia C, Hu X, Shi X, Jiang BH (2007) Apigenin inhibits tumor angiogenesis through decreasing HIF-1alpha and VEGF expression. Carcinogenesis 28:858-864

Gardner LB, Li Q, Park MS, Flanagan WM, Semenza GL, Dang CV (2001) Hypoxia inhibits G1/S transition through regulation of p27 expression. J Biol Chem 276:7919-7926

Giatromanolaki A, Koukourakis MI, Sivridis E, Turley H, Talks K, Pezzella F, Gatter KC, Harris AL (2001) Relation of hypoxia inducible factor 1 alpha and 2 alpha in operable non-small cell lung cancer to angiogenic/molecular profile of tumours and survival. Br J Cancer 85:881-890

Graeber TG, Osmanian C, Jacks T, Housman DE, Koch CJ, Lowe SW, Giaccia AJ (1996) Hypoxia-mediated selection of cells with diminished apoptotic potential in solid tumours. Nature 379:88-91

Hofer T, Wenger H, Gassmann M (2002) Oxygen sensing, HIF-1alpha stabilization and potential therapeutic strategies. Pflugers Arch 443:503-507

Iyer NV, Kotch LE, Agani F, Leung SW, Laughner E, Wenger RH, Gassmann M, Gearhart JD, Lawler AM, Yu AY, Semenza GL (1998) Cellular and developmental control of $\mathrm{O}_{2}$ homeostasis by hypoxia-inducible factor 1 alpha. Genes Dev 12:149-162

Jensen RL, Ragel BT, Whang K, Gillespie D (2006) Inhibition of hypoxia inducible factor-1alpha (HIF-1alpha) decreases vascular endothelial growth factor (VEGF) secretion and tumor growth in malignant gliomas. J Neurooncol 78:233-247

Jiang H, Feng Y (2006) Hypoxia-inducible factor 1alpha (HIF-1alpha) correlated with tumor growth and apoptosis in ovarian cancer. Int J Gynecol Cancer 16:405-412

Kimura S, Kitadai Y, Tanaka S, Kuwai T, Hihara J, Yoshida K, Toge T, Chayama K (2004) Expression of hypoxia-inducible factor (HIF)-1alpha is associated with vascular endothelial growth factor expression and tumour angiogenesis in human oesophageal squamous cell carcinoma. Eur J Cancer 40:19041912

Koukourakis MI, Giatromanolaki A, Sivridis E, Simopoulos C, Turley H, Talks K, Gatter KC, Harris AL (2002) Hypoxiainducible factor (HIF1A and HIF2A), angiogenesis, and chemoradiotherapy outcome of squamous cell head-and-neck cancer. Int J Radiat Oncol Biol Phys 53:1192-1202

Liu L, Ning X, Sun L, Zhang H, Shi Y, Guo C, Han S, Liu J, Sun S, Han Z, Wu K, Fan D (2008) Hypoxia-inducible factor-1 alpha contributes to hypoxia-induced chemoresistance in gastric cancer. Cancer Sci 99:121-128

Mabjeesh NJ, Amir S (2007) Hypoxia-inducible factor (HIF) in human tumorigenesis. Histol Histopathol 22:559-572

Magnon C, Opolon P, Ricard M, Connault E, Ardouin P, Galaup A, Metivier D, Bidart JM, Germain S, Perricaudet M, Schlumberger M (2007) Radiation and inhibition of angiogenesis by canstatin synergize to induce HIF-1alpha-mediated tumor apoptotic switch. J Clin Invest 117:1844-1855
Matthews NE, Adams MA, Maxwell LR, Gofton TE, Graham CH (2001) Nitric oxide-mediated regulation of chemosensitivity in cancer cells. J Natl Cancer Inst 93:1879-1885

Maxwell PH, Wiesener MS, Chang GW, Clifford SC, Vaux EC, Cockman ME, Wykoff CC, Pugh CW, Maher ER, Ratcliffe PJ (1999) The tumour suppressor protein VHL targets hypoxia-inducible factors for oxygen-dependent proteolysis. Nature 399:271-275

Nagle DG, Zhou YD (2006) Natural product-based inhibitors of hypoxia-inducible factor-1 (HIF-1). Curr Drug Targets 7:355-369

O'Donnell JL, Joyce MR, Shannon AM, Harmey J, Geraghty J, Bouchier-Hayes D (2006) Oncological implications of hypoxia inducible factor-1alpha (HIF-1alpha) expression. Cancer Treat Rev 32:407-416

Ogiso Y, Tomida A, Lei S, Omura S, Tsuruo T (2000) Proteasome inhibition circumvents solid tumor resistance to topoisomerase II-directed drugs. Cancer Res 60:2429-2434

Oikawa M, Abe M, Kurosawa H, Hida W, Shirato K, Sato Y (2001) Hypoxia induces transcription factor ETS-1 via the activity of hypoxia-inducible factor-1. Biochem Biophys Res Commun 289:39-43

Partridge SE, Aquino-Parsons C, Luo C, Green A, Olive PL (2001) A pilot study comparing intratumoral oxygenation using the comet assay following $2.5 \%$ and $5 \%$ carbogen and $100 \%$ oxygen. Int J Radiat Oncol Biol Phys 49:575-580

Piret JP, Cosse JP, Ninane N, Raes M, Michiels C (2006) Hypoxia protects HepG2 cells against etoposide-induced apoptosis via a HIF-1-independent pathway. Exp Cell Res 312:2908-2920

Roninson IB, Abelson HT, Housman DE, Howell N, Varshavsky A (1984) Amplification of specific DNA sequences correlates with multi-drug resistance in Chinese hamster cells. Nature 309:626-628

Roninson IB, Chin JE, Choi KG, Gros P, Housman DE, Fojo A, Shen DW, Gottesman MM, Pastan I (1986) Isolation of human mdr DNA sequences amplified in multidrug-resistant KB carcinoma cells. Proc Natl Acad Sci U S A 83:4538-4542

Sampath J, Sun D, Kidd VJ, Grenet J, Gandhi A, Shapiro LH, Wang Q, Zambetti GP, Schuetz JD (2001) Mutant p53 cooperates with ETS and selectively up-regulates human MDR1 not MRP1. J Biol Chem 276:39359-39367

Schindl M, Schoppmann SF, Samonigg H, Hausmaninger H, Kwasny W, Gnant M, Jakesz R, Kubista E, Birner P, Oberhuber G (2002) Overexpression of hypoxia-inducible factor 1 alpha is associated with an unfavorable prognosis in lymph node-positive breast cancer. Clin Cancer Res 8:1831-1837

Schnitzer SE, Schmid T, Zhou J, Brune B (2006) Hypoxia and HIF1alpha protect A549 cells from drug-induced apoptosis. Cell Death Differ 13:1611-1613

Semenza GL (1999) Regulation of mammalian $\mathrm{O}_{2}$ homeostasis by hypoxia-inducible factor 1 . Annu Rev Cell Dev Biol 15:51-78

Semenza GL (2000) Surviving ischemia: adaptive responses mediated by hypoxia-inducible factor 1 . J Clin Invest 106:809-812

Semenza GL (2001) HIF-1 and mechanisms of hypoxia sensing. Curr Opin Cell Biol 13:167-171

Semenza G (2002) Signal transduction to hypoxia-inducible factor 1. Biochem Pharmacol 64:993-998

Sullivan R, Pare GC, Frederiksen LJ, Semenza GL, Graham CH (2008) Hypoxia-induced resistance to anticancer drugs is associated with decreased senescence and requires hypoxia-inducible factor-1 activity. Mol Cancer Ther 7:1961-1973

Teicher BA (1994) Hypoxia and drug resistance. Cancer Metastasis Rev 13:139-168

Thomlinson RH, Gray LH (1955) The histological structure of some human lung cancers and the possible implications for radiotherapy. Br J Cancer 9:539-549

Wartenberg M, Fischer K, Hescheler J, Sauer H (2000) Redox regulation of P-glycoprotein-mediated multidrug resistance in multicellular prostate tumor spheroids. Int J Cancer 85:267-274 
Wartenberg M, Donmez F, Ling FC, Acker H, Hescheler J, Sauer $\mathrm{H}$ (2001a) Tumor-induced angiogenesis studied in confrontation cultures of multicellular tumor spheroids and embryoid bodies grown from pluripotent embryonic stem cells. Faseb J 15:995-1005

Wartenberg M, Ling FC, Schallenberg M, Baumer AT, Petrat K, Hescheler J, Sauer H (2001b) Down-regulation of intrinsic $\mathrm{P}$-glycoprotein expression in multicellular prostate tumor spheroids by reactive oxygen species. J Biol Chem 276:17420-17428

Wartenberg M, Ling FC, Muschen M, Klein F, Acker H, Gassmann M, Petrat K, Putz V, Hescheler J, Sauer H (2003) Regulation of the multidrug resistance transporter P-glycoprotein in multicellular tumor spheroids by hypoxia-inducible factor (HIF-1) and reactive oxygen species. Faseb J 17:503-505

Weissenberger C, Fiebig HH, Lutterbach J, Barke A, Momm F, Muller M, Witucki G, Guttenberger R, Berger DP (2000) Is there any correlation between MDR1, GST-pi-expression and CEA? Anticancer Res 20:5139-5144

Welsh SJ, Bellamy WT, Briehl MM, Powis G (2002) The redox protein thioredoxin-1 (Trx-1) increases hypoxia-inducible factor 1alpha protein expression: Trx-1 overexpression results in increased vascular endothelial growth factor production and enhanced tumor angiogenesis. Cancer Res 62:5089-5095

Wenger RH, Camenisch G, Desbaillets I, Chilov D, Gassmann M (1998) Up-regulation of hypoxia-inducible factor-1alpha is not sufficient for hypoxic/anoxic p53 induction. Cancer Res 58:5678-5680

Wu XA, Sun Y, Fan QX, Wang LX, Wang RL, Zhang L (2007) Impact of RNA interference targeting hypoxia-inducible factor-1alpha on chemosensitivity in esophageal squamous cell carcinoma cells under hypoxia. Zhonghua Yi Xue Za Zhi 87:2640-2644

Yu JX, Cui L, Zhang QY, Chen H, Ji P, Wei HJ, Ma HY (2006) Expression of NOS and HIF-1alpha in human colorectal carcinoma and implication in tumor angiogenesis. World J Gastroenterol 12:4660-4664

Zhong H, De Marzo AM, Laughner E, Lim M, Hilton DA, Zagzag D, Buechler P, Isaacs WB, Semenza GL, Simons JW (1999) Overexpression of hypoxia-inducible factor 1alpha in common human cancers and their metastases. Cancer Res 59:5830-5835 